\title{
Effects of Bt corn pollen on honey bees: emphasis on protocol development*
}

\author{
Robyn Rose ${ }^{\mathrm{a}}$, Galen P. DIVELY ${ }^{\mathrm{b}}$, Jeff PETTIS ${ }^{\mathrm{c}}$ \\ a Biotechnology Regulatory Services, USDA, Animal and Plant Health Inspection Service, Unit 147, 4700 River \\ Road, Riverdale, MD 20737, USA \\ ${ }^{b}$ Department of Entomology, University of Maryland, 4112 Plant Sciences Bldg., College Park, MD 20402, USA \\ ${ }^{c}$ Bee Research Laboratory, USDA, Agricultural Research Service, BLDG. 476, RM.100, BARC-EAST, \\ Beltsville, MD 20705, USA
}

Received 9 January 2006 - Revised 26 February 2007 - Accepted 28 February 2007

\begin{abstract}
Laboratory feeding studies showed no effects on the weight and survival of honey bees feeding on Cry1 Ab-expressing sweet corn pollen for 35 days. In field studies, colonies foraging in sweet corn plots and fed Bt pollen cakes for 28 days showed no adverse effects on bee weight, foraging activity, and colony performance. Brood development was not affected by exposure to Bt pollen but significantly reduced by the positive insecticide control. The number of foragers returning with pollen loads, pollen load weight, and forager weight were the most consistent endpoints as indicators of foraging activity. Using variances of measured endpoints, experimental designs required to detect a range of effect sizes at $80 \%$ statistical power were determined. Discussed are methods to ensure exposure to pollen, duration of exposure, positive controls, and appropriate endpoints to consider in planning laboratory and field studies to evaluate the nontarget effects of transgenic pollen.
\end{abstract}

Apis mellifera / Cry1Ab / power analysis / transgenic plants / risk assessment

\section{INTRODUCTION}

Laboratory studies to assess potential nontarget effects of Bt corn on honey bees, Apis mellifera $\mathrm{L}$., have involved feeding Bt pollen or purified endotoxin mixed with honey or sugar syrup directly to the larvae (Arpaia, 1996; Malone et al., 1999; Hanley et al., 2003). These studies and others have indicated no adverse effects, however, the method of endotoxin delivery has been questioned because it does not mimic the way pollen is naturally processed and fed to larvae (Hilbeck et al., 2000). Furthermore, exposure to Bt pollen could have other direct and indirect non-target effects on brood development in a honey bee

Corresponding author: G.P. Dively, galen@umd.edu

* Manuscript editor: Jean-Noël Tasei colony. For young bees, the presence of Bt proteins in ingested pollen may affect hypopharyngeal gland development and thus the ability of nurse bees to make brood food. Effects on the orientation, foraging, and communication behavioral activities could also impair the ability of worker bees to find and relocate food sources. Although experimental methods are available for assessing behavioral changes (Pham-Delègue et al., 2002), these potential sublethal effects of Bt corn have not been addressed in current laboratory protocols. Thus, reliable experimental protocols that evaluate the potential risks of Bt crops on honey bees are needed (Stark et al., 1995, Hilbeck et al., 2000). Reported here are results of both laboratory and field studies to assess the effects of $\mathrm{Bt}$ pollen on honey bee survival, foraging activity, and colony performance. A major emphasis of this research was to identify 
reliable endpoints and experimental protocols for assessing effects with acceptable statistical power. Bt sweet corn expressing the Cry1 Ab protein was chosen to represent worst-case exposure conditions because it produces greater amounts of pollen and is more attractive to honey bees than field corn (Schur et al., 2000; Sommerville, 2001).

\section{MATERIALS AND METHODS}

\subsection{Laboratory studies on adult survival and pollen consumption}

No-choice dietary feeding studies were conducted in 2001 and 2002 to measure effects of corn pollen on development and survival of adult honey bees. Cohorts of newly-emerged bees were fed a diet of Bt pollen from sweet corn hybrid Attribute GSS0966 (Syngenta Seeds, Golden Valley, $\mathrm{MN}$; event Bt11) and non-Bt pollen from an isoline (Syngenta Seeds; Prime Plus). Corn pollen was collected from plant tassels in the field, and stored at $-80{ }^{\circ} \mathrm{C}$ until initiation of the study. Bee cohorts were provided access to pollen, sugar syrup and water sources in small wooden cages $(11 \mathrm{~cm} \times 9 \mathrm{~cm} \times$ $7 \mathrm{~cm}$ ) with a sliding glass front, which allowed daily counting and removal of dead bees. Cages were kept in an incubator at $34{ }^{\circ} \mathrm{C}, 50 \% \mathrm{RH}$, and $24 \mathrm{~h}$ of dark. Bee mortality was recorded daily and the body weights of ten randomly selected bees were recorded on day 10.

In 2001, Bt, non-Bt, and mixed pollen (from pollen traps) diets were fed to newly emerged bees $(<24 \mathrm{~h}$ old $)$. Six replicate cages were assigned to each diet treatment. Each cage contained 60 bees randomly selected from one of six source colonies. Two grams of powdered pollen in an artificial plastic comb were placed in each cage on days 0,5 and 10. Small plastic lures with queen pheromone (Bee Boost, Pherotech Inc, Delta B.C., Canada) were placed in cages to simulate the presence of a queen. The amount of pollen consumed was determined on days 5,10 and 26 for each treatment cage by weighing pollen before and after introduction.

In 2002, cohorts of 50 newly emerged bees from ten source colonies were evenly allocated to three sets of 10 replicate cages. Treatments of Bt pollen, non-Bt pollen, or non-Bt pollen treated imidacloprid (Admire 2F, Bayer CropSciences, Research Triangle, NC) were assigned to each replicate set. The pollen types were mixed with honey to increase consumption and were provided on days $0,7,14$ as $5 \mathrm{~g}$ cakes ( $80 \%$ pollen and $20 \%$ honey w/w). Imidacloprid was added to the non-Bt pollen at the rate of $200 \mu \mathrm{g}$ per $\mathrm{kg}$ of cake. The difference in weights of pollen cakes before and after introduction was determined on days 7, 14 and 21 .

\subsection{Field studies on colony activity and development}

In 2002 four $65 \mathrm{~m} \times 65 \mathrm{~m}$ (0.4 ha) replicate plots of Bt hybrid Attribute GSS0966 (Syngenta Seeds) and its non-Bt isoline Prime Plus were planted at least $300 \mathrm{~m}$ apart from each other at University of Maryland Research facilities. Two plots of non-Bt sweet corn were also planted for positive control colonies exposed to imidacloprid.

Packages of $900 \mathrm{~g}$ of bees (approximately 10000 ) were obtained from a commercial supplier (Wilbanks Apiaries; Claxton, GA, USA) and used to establish colonies for 5-6 weeks prior to initiation of the field study. Sister queens from the same breeding line were used in these colonies which were established in nucleus hives with four brood frames and one foundation frame to allow for expansion. Two weeks prior to anthesis, hives were opened to visually assess and equalize bee and brood densities. Seven days prior to anthesis, three hives were randomly selected and placed on wooded pallets over a $3 \mathrm{~m} \times 4 \mathrm{~m}$ tarp in a cleared area at the center of each plot. During the evening of the same day, each hive was opened and sides of each comb with bees were photographed with a digital camera. Bees were then dislodged into the hive box and each comb photographed a second time to obtain pre-exposure images of brood, pollen, and honey cells.

Colonies were allowed to forage for 4 weeks, which overlapped the period of anthesis. No pollen loads were trapped to avoid interference with the functioning of the nucleus hive. Each colony was provisioned with pollen cakes to increase the level of exposure. Pollen was collected from plants within each respective plot and processed into $50 \mathrm{~g}$ cakes consisting of 2 parts pollen, 2 parts soy flour, 2 parts honey, and 1 part sugar by weight. Pollen cakes containing either 10,100 or $1000 \mu \mathrm{g}$ of imidacloprid per $\mathrm{kg}$ of cake were assigned to one of the three hives in each positive control plot. Concentrations were based on studies conducted to assess the impact of imidacloprid on honey bee behavior in France (Schmuck, 1999). Four cakes were 
placed directly on the top of the frames in each hive once or twice weekly to allow bees ad libitum access. Records were kept on the weight of pollen cakes consumed by each colony.

Hives were observed three times weekly during the exposure period to record the number of foraging bees returning to the hive, with and without pollen pellets, over a 5-min. period between 0900 and $1100 \mathrm{~h}$. Weights of foraging bees and their pollen loads were measured once weekly from a sample of 10 bees returning to hives. At the end of the exposure period, combs of each hive were again photographed to obtain post-exposure images of bee strength, brood development, and stores of food. The percentage of bees covering each comb, and the percentage of capped brood, pollen and honey cells were visually estimated to the nearest $10 \%$ from matching pre- and post-exposure images displayed on a computer monitor with a grid overlay. An actual count of bees was also recorded on representative grid sections showing 10 to $100 \%$ of the area covered with bees. This data set was used to compute a linear regression function to estimate the total number of bees per hive from the average percentage of combs covered with bees.

\subsection{Statistical analysis}

All data sets were tested before analysis for normality and homogeneity of variances using Spearman Rank Correlation and Shapiro-Wilk tests. For data not meeting the assumptions of ANOVA, an appropriate transformation was used or variances were grouped prior to analysis. Foraging data were analyzed as individual observations or as an average of weekly observations. Data on number of bees, and percentage of capped brood, pollen and honey cells were analyzed as differences between pre- and post-exposure conditions within each hive. The mean of the three hives per replicate plot were analyzed as the experimental unit, including the hives exposed to different doses of imidacloprid. The PROC MIXED procedure of ANOVA was used to test for main and interaction effects for each endpoint. The repeated measures option was used for time series data to correct for intercorrelation between sampling dates. Means were separated following a significant $\mathrm{F}$ test by using the Tukey's multiple comparison adjustment $(P<0.05)$. Contrast tests were performed to compare specific pollen diets individually or grouped. A variance component analysis (PROC MIXED Option CL) was con- ducted on specific endpoints to estimate the variance at each level of the experimental design.

A retroactive power analysis using PASS 2000 (Hintze, 2001) was performed using variance data to determine the number of replicates and subsamples (i.e. bees per cage, hives per plot) required to detect a range of effect sizes at $80 \%$ statistical power. An $80 \%$ probability of rejecting a false null hypothesis (Type II error) was chosen as the accepted level of power for non-target risk assessment studies (Candolfi et al., 2000).

\section{RESULTS}

\subsection{Laboratory studies}

Overall survival of bees in the 2001 study averaged $47.2 \%$ after feeding for 35 days and was not significantly affected by the pollen diets (Fig. 1). Differences in the amount of each pollen diet consumed per bee were not the same over time $(F=$ 5.17; $\mathrm{df}=4,30 ; P=0.003$ ). Adult bees consumed more mixed pollen than corn pollen but this preference declined significantly as the bees aged and apparently utilized less pollen in their diet. Bees fed non-Bt, Bt, and mixed corn pollen weighed $126.6 \pm 6.7,137.4 \pm 3.6$, and $139.6 \pm 2.2 \mathrm{mg}$, respectively, but differences were not statistically significant $(P=0.13)$.

In the 2002 study, survival of bees fed imidacloprid-treated pollen cakes was significantly reduced, particularly during the first five days, but there was no difference in the survival of bees fed $\mathrm{Bt}$ and non-Bt pollen $(\mathrm{F}=1.92 ; \mathrm{df}=40,460$; $P<0.001$ ) (Fig. 2). The average survival at 21 days for the non-Bt exposed bees was $71.4 \pm 20.6 \%$. Because the variance was relatively low, power analysis indicated that ten cohorts of 50 bees per treatment can detect a $35 \%$ difference in survival with $80 \%$ statistical power, assuming a one-tailed significance level of 0.05 .

As expected the amount of pollen ingested per bee was higher than the amount consumed by bees in the 2001 study. Differences in pollen consumption were statistically significant among pollen diets $(\mathrm{F}=10.43$, df $=2,15.9 ; P=0.001)$ (Fig. 2). More non-Bt than Bt pollen was consumed per bee but there was no difference between the non- $\mathrm{Bt}$ and imidacloprid-exposed bees. This result differed from the 2001 study that indicated no difference in $\mathrm{Bt}$ than non-Bt pollen consumption. Differences in pollen consumption and diets had no effect on bee weight. 


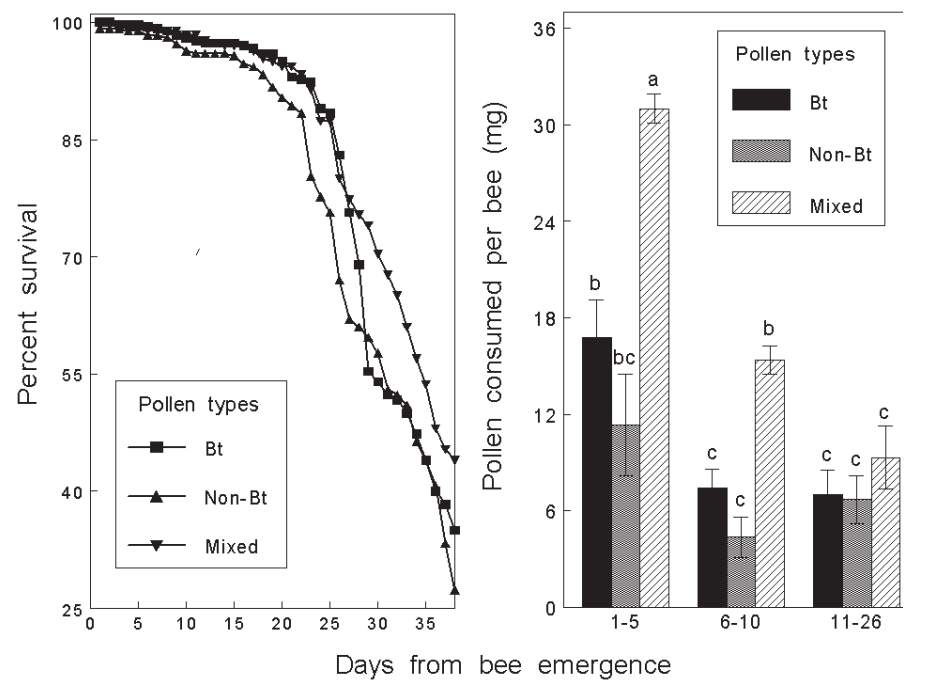

Figure 1. Survival and pollen consumption of honey bees fed Bt and non-Bt sweet corn, and mixed pollen from natural sources for 35 days in a no-choice laboratory study conducted in 2001. Mean bars with S.D. bearing the same letter are not significantly different at the 5\% probability level.

\subsection{Field Study}

\subsubsection{Foraging activity}

Exposure of bees to sweet corn plots and pollen cakes had no significant effect on foraging activity $(P=0.75)$ or the percentage of bees loaded with pollen $(P=0.54)$. Noteworthy is the fact that bees from the imidacloprid-exposed hives were foraging at about the same level of activity but overall $22 \%$ fewer bees were bringing back pollen, particularly during the last week of exposure. Due to the low replication, the percentage of foragers loaded with pollen (14 to $29 \%$ ) was not significantly different among the three imidacloprid concentrations $(P=0.065)$. However, $50 \%$ fewer foragers from hives exposed to the high rate of imidacloprid were returning with pollen compared to foragers exposed to the lower doses.

Foraging bee weights averaged $80.1 \pm 1.34$, $80.6 \pm 2.45$, and $77.4 \pm 3.40 \mathrm{mg}$, and pollen loads averaged $8.6 \pm 0.84,7.7 \pm 0.88$, and $5.5 \pm 0.57 \mathrm{mg}$ for hives exposed to $\mathrm{Bt}$, non-Bt, and imidacloprid, respectively. There were no statistical differences among treatments. However, the overall weight of pollen loads significantly increased over time $(F=$ $3.93 ; \mathrm{df}=2,12 ; P=0.049$ ).

The most consistent endpoints of foraging activity were the percentage of foragers returning with pollen loads, pollen load weight, and foraging bee weight. Based on the level of replication in the field study, a $40 \%$ reduction in these endpoints from the control response should be detectable with $80 \%$ power (Fig. 3). The majority of variation in foraging activity was due to hives between replicate plots rather than hives within plots. Thus, less gain in statistical power is achieved by increasing the number of hives beyond three per plot.

\subsubsection{Colony performance}

During the exposure period, colonies in all hives consumed an average of $7.9 \pm 0.78 \mathrm{~g}$ of pollen per day by feeding on the pollen cakes. The relative change in the amount of capped brood was the only hive measurement significantly affected by the treatments $(\mathrm{F}=12.52 ; \mathrm{df}=2,4 ; P=0.019)$ (Fig. 4). The percentage change in brood increased by 1.5 and $31.7 \%$ in the Bt and non-Bt plots, respectively, and was not statistically significant $(P=0.06)$ whereas it significantly decreased by $18.9 \%$ in the imidacloprid exposed plots $(P=0.013)$.

Colony population size and measurements of pollen and honey stores were quite variable and thus less reliable to detect relative changes in hive performance. Given the level of replication in this study, only differences in stores of pollen and honey greater than $75 \%$ from the control could be detected with $80 \%$ power. Although the relative change in 


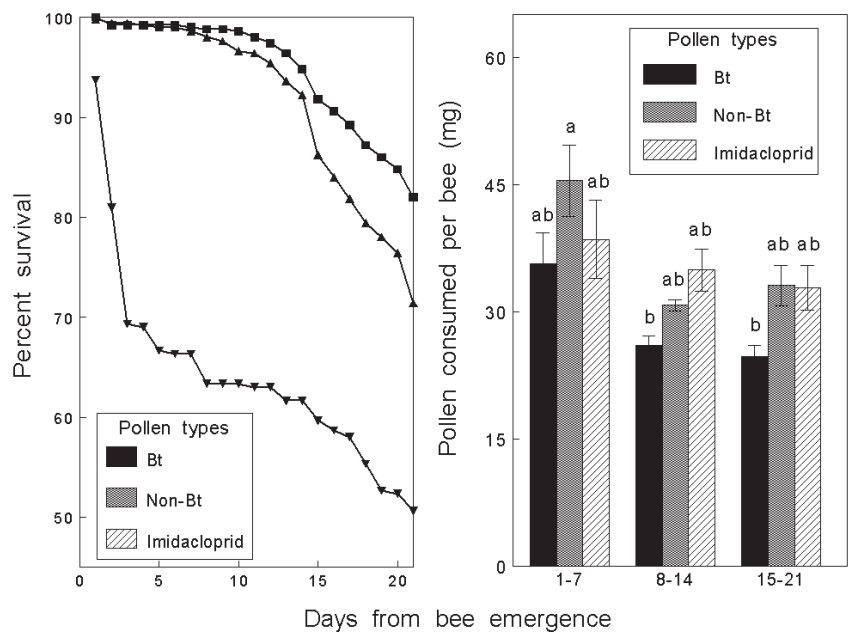

Figure 2. Survival and pollen consumption of bees fed Bt, non-Bt and treated sweet corn pollen for 20 days in a no-choice laboratory study conducted in 2002. The treated pollen contained $200 \mu \mathrm{g}$ of imidacloprid per kg of cake. Mean bars with S.D. bearing the same letter are not significantly different at the 5\% probability level.

the percentage of capped brood cells was significantly affected by the positive control, this endpoint was also too variable to detect a $50 \%$ effect size with $80 \%$ power. Given the variation in brood development, experimental designs to evaluate changes in brood strength should include four hives in each of six replicate plots to detect a $50 \%$ difference from the control response (Fig. 5).

\section{DISCUSSION}

\subsection{Laboratory studies}

Dietary toxicity tests for Bt proteins have involved dosing larval honey bees with endotoxins or Bt pollen (EPA, 2001) whereas in our study, newly emerged bees were fed different pollen types for up to 35 days to assess the effects on pollen consumption and, survival. Bees consumed significantly more mixed pollen than sweet corn pollen and more sweet corn pollen when it was mixed with honey. Inconsistent results in pollen consumption were observed between the non-Bt and Bt cohorts of bees, which were probably due to differences in pollen quality since the two types of sweet corn pollen were not collected at the same time. Cry1 Ab expression in pollen has been reported as $<0.09 \mu \mathrm{g} / \mathrm{g}$ for event Bt11 field corn (EPA, 2000a). Considering this concentration as a realistic worst case we presume our individual bees consumed on average $2.8 \mathrm{ng}$ of toxin over 26 days in 2001 and $6.2 \mathrm{ng}$ over 21 days in 2002. This level of experimental exposure was less than the 10 day exposures of purified endotoxins used in the laboratory at $625 \mu \mathrm{g} / \mathrm{g}$ Cry $1 \mathrm{Ba}$ and $10 \mu \mathrm{g} / \mathrm{g}$ Cry $1 \mathrm{Ab}$ by Malone et al. (2004) and Babendreier et al. (2005) respectively, who did not report negative effects on bee survival. All these studies are in agreement with Hanley's et al. results (2003) and EPA reports (2001) that indicated no adverse effects when Cry1 Ab field corn pollen was fed directly to honey bee larvae in brood cells.

Based on our laboratory studies, the following guidelines will aid in developing a protocol for assessing the effects of Bt corn pollen on newly emerged bees. First, variance can be reduced and statistical power increased by establishing replicate cohorts from a more homogenous pool of honey bees collected from one representative colony. Also, one-tailed testing will increase statistical power and is appropriate for survival data because only reductions relative to the control indicate a potential risk or the need for higher tier studies. Laboratory studies to measure adult bee survival should test at least six cohorts of 50 bees per treatment to detect a $50 \%$ reduction with $80 \%$ statistical power. To ensure maximum consumption and exposure to the expressed protein, fresh pollen should be mixed with honey and fed to cohorts of adults for 


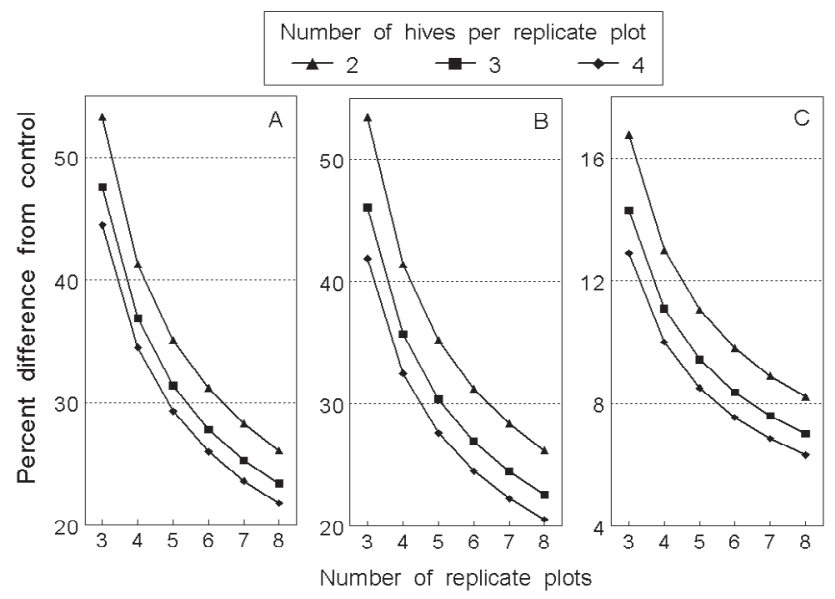

Figure 3. Number of replicate plots and number of hives per plot required in field studies to detect a range of differences in: A, the number of foraging bees returning to hives with pollen loads; B, weight of pollen loads carried back to hives by foraging bees; $\mathrm{C}$, weight of foraging bees from the control at $80 \%$ statistical power. Variance and mean values for power calculations are based on counts per five minutes at the entrance of the hive, and average weights of ten pollen loads and bees combined per replicate.
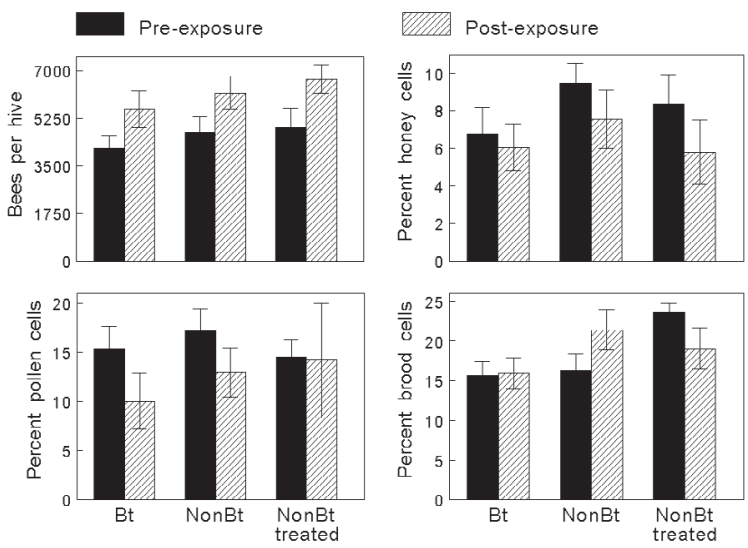

Figure 4. Pre- and post-exposure estimates of colony population size, and the percentages of honey, pollen or capped brood cells. Data are shown for hives exposed to three types of sweet corn pollen cakes: non-Bt, $\mathrm{Bt}$ or non-Bt treated with imidacloprid and placed in plots of non-Bt, Bt and non-Bt sweet corn, respectively.

at least 21 days. Mortality should be recorded at weekly intervals, although survival data collected at 21 days is a reliable endpoint for detecting differences. Hypopharyngeal glandular development should be assessed in newly-emerged bees after 10 days of exposure. Head weight has been directly correlated to the development and size of hypopharyngeal glands (Hrassnigg and Crailsheim, 1998; Babendreier et al., 2005) and used to test the effect of pesticides (Gupta and Chandel, 1995). Although not reported here, preliminary data on head weight indicated that a large sample size would be required due to the high variance and small changes in head weight that could indicate an adverse effect. The actual gland size and acini diameter measured directly by dissection of the bee head may be more appropriate endpoints (Malone et al., 2004; Babendreier et al., 2005). Since glandular development is influenced by the presence of brood (Hrassnigg and Crailsheim, 1998), a section of comb containing eggs should be included in the rearing cages. The test arena also should include a 


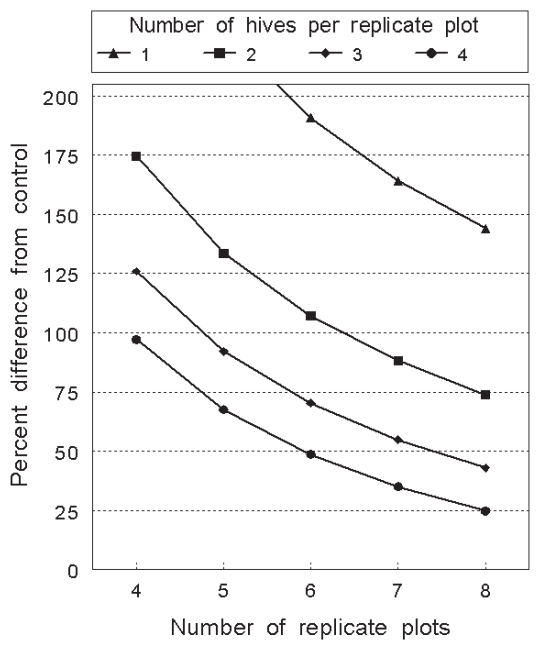

Figure 5. Number of replicate plots and number of hives per plot required in field studies to detect a range of differences in brood size from the control response at $80 \%$ statistical power.

queen attached to the cages or queen pheromone to provide a more natural environment for caged bees. A positive control, preferably a toxic gut-active protein or chemical, should be included to confirm that the bees are exposed to the test protein. The $200 \mu \mathrm{g}$ per $\mathrm{kg}$ dose of imidacloprid was too high for stressing cohorts. Ideally, a lower dose that causes the smallest adverse effect but still statistically significant from the negative control is preferred because it both confirms exposure and provides information on the sensitivity of the test procedure.

\subsection{Field studies}

This study represents the first attempt to expose functional colonies of honey bees to Bt corn pollen under open field conditions. No significant effects of exposure to Bt pollen on foraging behavior, bee body weight, and colony performance were detected. These results agree with other studies conducted either in the field (caged colonies) or in the laboratory that reported no effects of Bt pollen or Cry proteins on honey bees (Schur et al., 2000; Malone and Pham-Delegue, 2001).

Experimental procedures to ensure exposure to pollen should be taken into consideration when assessing the risk of transgenic crops to honey bees in a field situation. During the exposure period of late July-early August our free flying colonies were not likely to visit plant species more attractive than corn in the surroundings. In addition bees were observed foraging on the corn tassels during anthesis. Nevertheless it cannot be ascertained these bees were from our experimental hives since the foraging radius of honey bees from the colony ranges from a few hundred meters to $10 \mathrm{~km}$ in agricultural areas (Seeley, 1995). Several methods could be used to verify the presence of sweet corn pollen in the hives. Samples of pollen pellets from returning bees or stored pollen in combs could be processed and counted for corn pollen content (Jones and Coppedge, 2000). Enzyme-linked immunosorbent assays (ELISA) have been used in other studies (Wraight et al., 2000; Chilcutt and Tabashnik, 2004) to confirm that corn pollen contains $\mathrm{Cry} 1 \mathrm{Ab}$ protein. However, the level of expression in Bt sweet corn pollen may be too low to accurately detect its presence (D. Vlachos, Syngenta, personal communication). Even if an ELISA approach is feasible, it still cannot quantify the exposure level of active protein or confirm that pollen from foraging bees or stored pollen came from sweet corn plants within the plots. A direct and quantitative route of exposure is by providing pollen cakes to hives and measuring the amount consumed during the exposure period. In this study, pollen cake consumption represented approximately $44 \%$ of the expected daily pollen requirements of a small hive of 5000 bees (Seeley, 1995; Crailsheim et al., 1992; J. Pettis, personal communication), indicating that colonies were exposed to a substantial dosage of Bt pollen. If the 
aim is to evaluate effects of worst case exposure, purified Cry toxins should be incorporated into pollen cakes and provisioned to hives as did Malone et al. (2001) and Huang et al. (2004) or into syrup according to Arpaia (1996) and Picard-Nizou et al. (1997).

An insecticide positive control was included in this study to verify that bees and brood in the hives were exposed to the treatments. Dosage levels of 10 , 100 or $1000 \mu \mathrm{g} / \mathrm{kg}$ of imidacloprid incorporated into pollen cakes resulted in an overall $20 \%$ reduction in the number of brood cells, confirming that consumption of the pollen cakes was either adversely affecting the number of nurse bees or contaminating brood food. However the minimum dose that would cause a detectable effect could not be determined due to our design comprising one hive per dose in two replicate plots. Considering contradictory conclusions on imidacloprid concentrations resulting in no chronic effect (Maus et al., 2003) or in significant effects on survival or behavior (Suchail et al., 2001; Ramirez-Romero et al., 2005), we suggest that a concentration of around $100 \mu \mathrm{g}$ of imidacloprid per $\mathrm{kg}$ in pollen cakes may be a reasonable positive control. However a positive control is not necessary if a maximum level of exposure to the transgenic toxin is accurately measured.

Another important consideration in a non-target field study of honey bee colonies is the duration of the exposure. In this study, functional hives were exposed to Bt pollen for at least four weeks after which hive performance was measured and compared with pre-exposure levels. The exposure period could not be extended any longer due to possible confounding effects from physiological changes in bees preparing for overwintering. However, longer experimental durations may be more desirable to detect possible delayed chronic effects if the exposure period starts earlier in the summer.

Non-target field studies are often criticized because the level of replication does not provide enough statistical power to detect potential differences between the treatments and control. A generally accepted aim in ecotoxicological studies is to detect a $50 \%$ difference relative to the control response with $80 \%$ statistical power (Candolfi et al., 2000). Using this as a standard, retrospective power analyses were conducted on each endpoint to determine the number of plots and hives needed to detect a range of effect sizes. Also, the power of testing is dependent partly on the selection of relevant endpoints that are the most sensitive and consistent in response to non-target effects. Given the level of replication and the imperfect equalization of hives at the beginning of our experiment, the number of foragers returning, hive population size, and measurements of pollen and honey stores were too variable to detect a 50\% effect size. The most consistent endpoints were the number of foragers returning with pollen loads, pollen load weight, and foraging bee weight. These endpoints can be used as indicators of the ability of foraging bees to locate sources of pollen and return to the hive. Noteworthy is that more statistical power is possible by focusing on the number of bees returning with pollen loads rather than counting returning foragers, which is the common indicator used in most foraging studies. The power analyses showed that experimental designs similar to the one used in this study should detect a $40 \%$ reduction in foraging endpoints with $80 \%$ power. For the colony performance endpoints, the analysis of differences between pre- and postexposure conditions reduced the inherent variability to some degree. The percentage of capped brood cells as an indicator of queen health and brood development did not differ between the Bt and nonBt treatments but was significantly reduced by the positive control. However, in future studies, at least four hives placed in six replicate plots would be needed to detect a $50 \%$ change in brood development with $80 \%$ statistical power. In field studies with multiple endpoints measured, the level of replication and subsampling should be designed to achieve enough statistical power for detecting 50\% changes in the most variable endpoint.

The EPA Scientific Advisory Panel held in 1999 (EPA, 2000b) recommended that field studies be conducted as the most direct way to assess potential non-target invertebrate impacts of planting $\mathrm{Bt}$ corn on a commercial scale This study has identified several experimental design elements, sensitive endpoints, and factors to consider in planning shortterm field studies with open, functional hives to evaluate the non-target effects of transgenic pollen. Although there is no evidence thus far of any lethal or sublethal effects of the Bt proteins, insecticidal products expressed by other transgenes may need more extended field testing on a case-by-case basis (Malone and Pham-Delegue, 2001) to assess the longer term consequences of sub-lethal changes in colonies and subtle modifications in bee behavior.

\section{ACKNOWLEDGEMENTS}

We thank Amy Miller, Terry Patton, Kelly Haisfeld, Adam Oaks, Jenny Rochico, Jessica 
Nelson, Ben Falk, Heather Harmon, Kaitlin Nelson, Bridgette Bobwiec, and Mika Hunter for assistance in the conducting field studies, and Mike Embrey for providing the bee colonies. Financial support was provided by the Maryland Agriculture Experiment Station and by a grant from the U.S. Environmental Protection Agency.

Les effets du pollen de maïs Bt sur les abeilles domestiques : étude mettant l'accent sur la mise au point d'un protocole expérimental.

\section{Apis mellifera / plante transgénique / évaluation risque / Cry1Ab / analyse puissance statistique / survie / consommation pollen / comportement butinage / performance colonie / étude en labo- ratoire / étude en champ}

Zusammenfassung - Auswirkungen von Pollen von Bt-Mais auf Honigbienen: Eine Untersuchung mit Schwerpunkt auf der Entwicklung von Versuchsprotokollen. Der Kontakt mit Pollen von CryIAb-exprimierenden Maispflanzen, die Gene des Bodenbakteriums Bacillus thuringiensis (Bt) enthalten, kann direkte oder indirekte Auswirkungen auf Honigbienen haben. Wir führten Laborund Feldstudien durch, um mögliche Effekte von Pollen von Bt-Süssmais auf verschiedene Indikatoren der Fitness und Volksleistung von Honigbienen zu erfassen. Die Laborstudien liessen keine Effekte auf das Lebendgewicht und die Überlebensraten von Bienen erkennen, die Bt-Pollen aufgenommen hatten (Abb. 1, 2). Der Zusatz von Honig erhöhte die Aufnahme von Pollen unter Laborbedingungen. Auch in den Feldstudien war weder nach Aufnahme von Pollen in Bt-Süssmaisparzellen noch nach Verzehr von Bt-Pollenkuchen über 28 Tage hinweg eine negative Auswirkung auf das Gewicht der Bienen, ihr Sammelverhalten oder auf die Kolonieleistung zu erkennen. Die beständigsten Endpunktindikatoren für das Sammelverhalten waren der Prozentsatz der mit Pollenhöschen zurückkehrenden Sammlerinnnen, das Gewicht der Pollenhöschen und das Gewicht der Sammlerinnen. Eine Reduktion in diesen Endpunkten um $40 \%$ im Vergleich zu den Kontrollen hätte bei den in dieser Feldstudien zugrundegelegten Wiederholungen mit einer Wahrscheinlichkeit von $80 \%$ erkennbar sein müssen (Abb. 3). Die Volksgrösse und die Messungen der Pollen- und Honigvorräte waren hingegen mit ziemlichen Schwankungen verbunden und lieferten weniger verlässliche Indikatoren für die Volksleistung. Unter den dieser Studie zugrundegelegten Wiederholungen wären nur Unterschiede von über $75 \%$ in den entsprechenden Pollen- und Honigvorräten mit einer Wahrscheinlichkeit von $80 \%$ zu erkennen gewesen. Der Kontakt mit Bt-Pollen zeigte keine Effekte auf die Brutentwicklung. Diese war jedoch in den positiven Kontrollen mit In- sektizidkontakt (Imidacloprid) signifikant reduziert (Abb. 4). Angesichts der Unterschiede in der Brutnestgrösse sollten Experimente, die die Beurteilung von Auswirkungen auf die Brut zum Ziel haben, mit mindestens vier Völkern in jeder der sechs Replikaparzellen durchgeführt werden, wenn ein Unterschied von $50 \%$ im Vergleich zu Kontrollen erkennbar sein soll (Abb. 5). Wir diskutieren Methoden, die dazu beitragen sollen den Kontakt mit Pollen, die Kontaktdauer, die positiven Kontrollen, sowie die angemessenen Endpunkte abzusichern. Diese sollten für die Planung von Labor- und Feldstudien zu Auswirkungen von transgenem Pollen auf NichtZielorganismen von Nutzen sein.

\section{Apis mellifera / Cry1Ab / Potenzanalyse / Trans-} gene Pflanzen / Risikoabschätzung

\section{REFERENCES}

Arpaia S. (1996) Ecological impact of Bt-transgenic plants: Assessing possible effects of CryIIIB toxin on honey bees (Apis mellifera L.) colonies, J. Genet. Breed. 50, 315-319.

Babendreier D., Kalberer N.M., Romeis J., Fluri P., Mulligan E., Bigler F. (2005) Influence of Bttransgenic pollen, Bt-toxin and protease inhibitor (SBTI) ingestion on development of the hypopharyngeal glands in honeybees, Apidologie 36, 585594.

Candolfi M.P., Bluemel S., Forester R., Bakker F.M., Grimm C., Hassan S.A., Heimbach U., MeadBriggs M.A., Reber B., Schmuck R., Vogt H. (2000) Guidelines to evaluate side-effects of plant protection products to non-target arthropods: IOBC, BART and EPPO joint initiative, $158 \mathrm{p}$.

Chilcutt C.F., Tabashnik B.E. (2004) Contamination of refuges by Bacillus thuringiensis toxin genes from transgenic corn, Proc. Natl Acad. Sci. USA 101, $7526-7529$.

Crailsheim K., Schneider L.H.W., Hrassnigg N., Buhlmann G., Brosch U., Gmeinbauer R., Schoffmann B. (1992) Pollen consumption and utilization in worker honeybees (Apis mellifera carnica): dependence on individual age and function, J. Insect Physiol. 38, 409-419.

Environmental Protection Agency (2000a) SAP report No. 99-06, Characterization and non target organism data requirements for protein plant pesticides, http://www.epa.gov/scipoly/sap/1999/ index.htm\#december/backgrd1.pdf [online] (accessed on 19 April 2007).

Environmental Protection Agency (2000b) Bt Plant-Pesticides Biopesticides Registration Action Document, Science Assessment, http:// www.epa.gov/oscpmont/sap/meetings/2000/october/ brad2_scienceassessment.pdf [online] (accessed on 19 April 2007). 
Environmental Protection Agency (2001) Bt Plant - Pesticides Biopesticides Registration Action Document, Environmental Assessment, http:// www.epa.gov/oscpmont/sap/meetings/2000/october/ brad3_enviroassessment.pdf [online] (accessed on 19 April 2007).

Gupta P.R., Chandel R.S. (1995) Effects of diflubenzuron and penfluron on workers of Apis ceranaindica F. and Apis mellifera L., Apidologie 26, $3-10$.

Hanley A.V., Huang Z.Y., Pett W.L. (2003) Effects of dietary transgenic $\mathrm{Bt}$ corn pollen on larvae of Apis mellifera and Galleria mellonella, J. Apic. Res. 42, 77-81.

Hilbeck A., Meier M.S., Raps A. (2000) Review on Non-Target Organisms and Bt-Plants, EcoStrat $\mathrm{GmbH}$ (Ecological Technology Assessment \& Environmental Consulting), Report to Greenpeace International, Amsterdam, $77 \mathrm{p}$.

Hintze J. (2001) NCSS and PASS, Number cruncher statistical systems ${ }^{\mathrm{TM}}$, Kaysville, Utah, [online] http://www.ncss.com (accessed on 19 April 2007).

Hrassnigg N., Crailsheim K. (1998) Adaptation of hypopharyngeal gland development to the brood status of honeybee (Apis mellifera L.) colonies, J. Insect Physiol. 44, 929-939.

Huang Z.Y., Hanley A.V., Pett W.L., Langenberger M., Duan J.J. (2004) Field and semifield evaluation of impacts of transgenic canola pollen on survival and development of worker honey bees, J. Econ. Entomol. 97, 1517-1523.

Jones G.D., Coppedge J.R. (2000) Foraging resources of adult Mexican corn rootworm (Coleoptera: Chrysomelidae) in Bell County, Texas, J. Econ. Entomol. 93, 636-643.

Malone L.A., Pham-Delègue M.H. (2001) Effects of transgenic products on honey bees (Apis mellifera) and bumblebees (Bombus sp.), Apidologie 32, 287-304.

Malone L.A., Burgess E.P.J., Stefanovic D. (1999) Effects of a Bacillus thuringiensis toxin, two Bacillus thuringiensis biopesticide formulations, and a soybean trypsin inhibitor on honey bee (Apis mellifera $\mathrm{L}$.) survival and food consumption, Apidologie 30, 465-473.

Malone L.A., Burgess E.P.J., Gatehouse H.S., Voisey C.R., Tregidga E.L., Philip B.A. (2001) Effects of ingestion of a Bacillus thuringiensis toxin and a trypsin inhibitor on honey bee flight activity and longevity, Apidologie 32, 57-68.

Malone L.A., Todd J.H., Burgess E.P.J., Christeller J.T. (2004) Development of hypopharyngeal glands in adult honey bees fed with a Bt toxin, a biotin binding protein and a protease inhibitor, Apidologie $35,655-664$.

Maus C., Curé G., Schmuck R. (2003) Safety of imidacloprid seed dressings to honey bees: a comprehensive overview and compilation of the current state of knowledge, Bull. Insectology 56, 51-57.

Pham-Delègue M.H., Decourtye A., Kaiser L., Devillers J. (2002) Behavioural methods to assess the effects of pesticides on honey bees, Apidologie $33,425-432$.

Picard-Nizou A.L., Grison R., Olsen L., Pioche C., Arnold G., Pham-Delegue M.H. (1997) Impact of proteins used in plant genetic engineering: toxicity and behavioral study in the honeybee, J. Econ. Entomol. 90, 1710-1716.

Ramirez-Romero R., Chaufaux J., Pham-Delègue M.H. (2005) Effects of Cry1Ab protoxin, deltamethrin and imidacloprid on the foraging activity and the learning performances of the honeybee Apis mellifera, a comparative approach, Apidologie 36, 601-611.

Schmuck R. (1999) No causal relationship between Gauchoß seed dressing in sunflowers and the French bee malady, Pflanzenschutz-Nachrichten Bayer 52, 257-299.

Schur A., Tornier I., Neumann C. (2000) Assessment of potential side effects of Bt-corn to the honey bee, Apis mellifera (Hymenoptera, Apidae) under field conditions, Apidologie 31, 616-618.

Seeley T.D. (1995) The Wisdom of the Hive The Social Physiology of Honey Bee Colonies, Harvard University Press, Cambridge Massachusetts, $295 \mathrm{p}$.

Sommerville D.C. (2001) Nutritional value of bee collected pollens, a report for the Rural Industries Research and Development, Corporation \#01/047, NSW Agriculture Goulburn, NSW Kustry, 166 p.

Stark J.D., Jepson P.C., Mayer D.F. (1995) Limitations to use of topical toxicity data for predictions of pesticide side effects in the field, J. Econ. Entomol. 88, 1081-1088.

Suchail S., Guez D., Belzunces L. (2001) Discrepancy between acute and chronic toxicity I induced by imidacloprid and its metabolites in Apis mellifera, Environ. Toxicol. Chem. 20, 2482-2486.

Wraight C.L., Zangerl A.R., Carroll M.J., Berenbaum M.R. (2000) Absence of toxicity of Bacillus thuringiensis pollen to black swallowtails under field conditions, Proc. Natl Acad. Sci. USA 97, 7700-7703. 